\title{
An in vitro assessment of panel of engineered nanomaterials using a human renal cell line: cytotoxicity, pro-inflammatory response, oxidative stress and genotoxicity
}

Ali Kermanizadeh ${ }^{1 *}$, Sandra Vranic ${ }^{2}$, Sonja Boland ${ }^{2}$, Kevin Moreau², Armelle Baeza-Squiban², Birgit K Gaiser ${ }^{1}$, Livia A Andrzejczuk ${ }^{1}$ and Vicki Stone ${ }^{1}$

Background: It has been shown that nanomaterials (NMs) are able to translocate to secondary tissues one of the important being the kidneys. Oxidative stress has been implicated as a possible mechanism for NM toxicity, hence effects on the human renal proximal tubule epithelial cells (HK-2) treated with a panel of engineered nanomaterials (NMs) consisting of two zinc oxide particles (ZnO - coated - NM 110 and uncoated - NM 111), two multi walled carbon nanotubes (MWCNT) (NM 400 and NM 402), one silver (NM 300) and five $\mathrm{TiO}_{2}$ NMs (NM 101, NRCWE 001, 002, 003 and 004) were evaluated.

Methods: In order to assess the toxicological impact of the engineered NMs on HK-2 cells - WST-1 cytotoxicity assay, FACSArray, HE oxidation and the comet assays were utilised. For statistical analysis, the experimental values were compared to their corresponding controls using an ANOVA with Tukey's multiple comparison.

Results: We found the two ZnO NMs $\left(24 \mathrm{hr} \mathrm{LC}_{50}-2.5 \mu \mathrm{g} / \mathrm{cm}^{2}\right)$ and silver NM $\left(24 \mathrm{hr} \mathrm{LC}_{50}-10 \mu \mathrm{g} / \mathrm{cm}^{2}\right)$ were highly cytotoxic to the cells. The $\mathrm{LC}_{50}$ was not attained in the presence of any of the other engineered nanomaterials (up to $80 \mathrm{\mu g} / \mathrm{cm}^{2}$ ). All nanomaterials significantly increased IL8 and IL6 production. Meanwhile no significant change in TNF-a or MCP-1 was detectable. The most notable increase in ROS was noted following treatment with the Ag and the two ZnO NMs. Finally, genotoxicity was measured at sub-lethal concentrations. We found a small but significant increase in DNA damage following exposure to seven of the ten NMs investigated (NM 111, NRCWE 001 and NRCWE 003 being the exception) with this increase being most visible following exposure to $\mathrm{Ag}$ and the positively charged $\mathrm{TiO}_{2}$.

Conclusions: While the NMs could be categorised as low and highly cytotoxic, sub-lethal effects such as cytokine production and genotoxicity were observed with some of the low toxicity materials.

Keywords: Kidneys, Nanotoxicity, Inflammation, ROS, DNA damage

\section{Background}

The prefix "nano" was specifically coined for particles containing tens or hundreds of atoms, with dimensions at the scale of less than $100 \mathrm{~nm}$ [1]. It is this small size which is fundamental to the field of nanotechnology, although other physicochemical properties influence the physical, biological and toxicological properties of these manufactured materials [2]. The principal reason for

\footnotetext{
* Correspondence: A.Kermanizadeh@hw.ac.uk

'Heriot-Watt University, School of Life Sciences, John Muir building, Edinburgh EH14 4AS, UK

Full list of author information is available at the end of the article
}

producing and exploiting nanomaterials (NMs) is that their behaviour is fundamentally different from the bulk form of the same compound [2]. Accordingly, previously unexploited beneficial properties of a given material can be explored in its nano size range [2]. As a result the amount of interest in nanotechnology has risen exponentially across many fields aiming to exploit a wealth of opportunities. These applications include medicine, cosmetics, textiles, electronics and engineering. However, there is concern that the increased release and exposure to these engineered NMs could be potentially hazardous

\section{Biomed Central}

(c) 2013 Kermanizadeh et al.; licensee BioMed Central Ltd. This is an Open Access article distributed under the terms of the Creative Commons Attribution License (http://creativecommons.org/licenses/by/2.0), which permits unrestricted use, distribution, and reproduction in any medium, provided the original work is properly cited. 
in an occupational and consumer setting [3-5]. A thorough risk evaluation is urgently required to provide an improved understanding of the implication of exposure to different NMs and any potential threat to humans or the environment [6]. A very effective strategy for achieving this is in the form of a critical risk assessment. Risks are assessed based upon the level of exposure to the manufactured NM, toxicology (hazard) of the material in question, route of exposure and its bio-persistence. Hence, it is necessary to identify the hazards associated with NM exposure both in vitro and in vivo, to assemble a knowledge base on the potential toxicity associated with NM exploitation on human health [4].

It is widely accepted that the skin, lungs and the gastrointestinal tract (GIT) are in constant contact with the external environment, and it is thus not surprising to find all three systems being primary exposure sites for NMs [5]. However following exposure some NMs are able to translocate to secondary target organs located at a distance from the original point of entry, which includes the kidneys $[7,8]$.

The kidneys are principally responsible for the removal of metabolic waste such as urea and ammonia. However it is believed that other waste products and toxic substances such as NMs could also be excreted through urine [9]. The kidneys receive blood from the renal arteries which branch directly from the dorsal aorta. Despite their relatively small size, the kidneys receive approximately $20 \%$ of the entire cardiac output [10], making the organs highly susceptible to xenobiotics such as NMs [11]. In theory both the glomerular structures (during plasma filtration) and tubular epithelial cells may be exposed to NMs. Since the major function of the kidneys is to eliminate a variety of potentially harmful substances (including the potential excretion of NMs), these organs are extremely important targets for investigation with regards to nanomaterial exposure and hazard.

Previous experiments have demonstrated that mice exposed to copper NMs had severe damage to the proximal tubular cells [11], while Wang and colleagues observed glomerulonephritis and pathological degeneration of the renal proximal convoluted tubules following oral $\mathrm{TiO}_{2}$ administration [12]. Proximal tubule cells exhibit well developed basal infolding and an apical brush border, enabling intense pinocytic activity and variable transport and co-transport of particles [13], therefore these cells would be an important target for a nanotoxicological investigation. Hence, this in vitro study conducted as part of the European funded project ENPRA (Risk assessment of engineered nanoparticles) investigated the adverse effects of a panel of widely utilised engineered NMs (five $\mathrm{TiO}_{2}$, two $\mathrm{ZnO}$, two MWCNTs and one Ag) on the immortalized adult human renal proximal tubule epithelial cells (HK-2) with respect to cytotoxicity, oxidative stress, cytokine secretion and DNA damage.

\section{Methods}

\section{Nanomaterials}

Nanomaterials were purchased as stated: NM 101 (Hombikat UV100; rutile with minor anatase; $7 \mathrm{~nm}$ ), NM 110 (BASF Z-Cote; zincite, uncoated, $100 \mathrm{~nm}$ ), NM 111 (BASF Z-Cote; zincite coated with triethoxycaprylylsilane, 130 nm), NM 300 (RAS GmbH; Ag capped with polyoxylaurat Tween $20-<20 \mathrm{~nm}$ ), NM 400 (Nanocyl; entangled MWCNT, diameter $30 \mathrm{~nm}$, length $5 \mu \mathrm{m})$, NM 402 (Arkema Graphistrength C100; entangled MWCNT, diameter $30 \mathrm{~nm}$, length $20 \mu \mathrm{m}$ ). The above mentioned nanomaterials were sub-sampled under Good Laboratory Practice conditions and preserved under argon in the dark until use. These NMs were received from the European Commission Joint Research Centre (Ispra, Italy). The NRCWE samples were procured by the National Research Centre for the Working Environment. Sub-sampling was completed into $20 \mathrm{ml}$ Scint-Burk glass pp-lock with Alu-Foil (WHEA986581; Wheaton Industries Inc.) after pooling and mixing of the material. NRCWE 001, $\mathrm{TiO}_{2}$ rutile $10 \mathrm{~nm}$ was purchased from NanoAmor (Houston, USA) and also used for production of NRCWE $002\left(\mathrm{TiO}_{2}\right.$ rutile $10 \mathrm{~nm}$ with positive charge) and NRCWE $003\left(\mathrm{TiO}_{2}\right.$ rutile $10 \mathrm{~nm}$ with negative charge) using the procedures described previously [14]. NRCWE 004 $\left(\mathrm{TiO}_{2}\right.$ rutile $\left.94 \mathrm{~nm}\right)$ was purchased from $\mathrm{NaBond}$.

\section{Characterisation of the panel of engineered nanomaterials}

All the nanomaterials used in this study were characterised by a combination of analytical techniques in order to infer primary physical and chemical properties useful to understand their toxicological behaviour. A comprehensive list of the main physical and chemical properties of the panel NMs has been shown (Table 1) [Reproduced and modified from 14]. Furthermore the hydrodynamic size distributions and zeta potential of the NMs dispersed in the complete renal cell medium (K-SFM) and RPMI with 10\% FCS (RPMI-FCS) were determined in the $1-128 \mu \mathrm{g} / \mathrm{ml}$ concentration range by Dynamic Light Scattering (DLS) using a Malvern Metasizer nano series - Nano ZS (USA) (Table 1).

\section{Cell culture and treatment with nanomaterials}

The immortalized adult human renal proximal tubule epithelial cells (HK-2) were obtained from the American Type Culture Collection (ATCC, USA). The cells were maintained in Keratinocyte Serum Free Medium (Gibco, UK) containing $25 \mu \mathrm{l}$ of bovine (pituitary) extract, $0.2 \mathrm{ng} / \mathrm{ml}$ human recombinant epidermal growth factor and $100 \mathrm{U} / \mathrm{ml}$ penicillin/streptomycin (termed K-SFM) or RPMI (Sigma, France) with 10\% FCS and $100 \mathrm{U} / \mathrm{ml}$ 
Table 1 Main physicochemical characteristics of engineered nanomaterials investigated - reproduced from [14]

\begin{tabular}{|c|c|c|c|c|c|c|c|c|c|c|c|}
\hline ENM code & $\begin{array}{l}\text { ENM } \\
\text { type }\end{array}$ & Phase & XRD Size [nm] & TEM Size & Primary characteristics by TEM analysis & $\begin{array}{l}\text { Surface } \\
\text { area } \\
\text { (BET) } \\
{\left[\mathrm{m}^{2} / \mathrm{g}\right]}\end{array}$ & Known coating & $\begin{array}{l}\text { Size in } \\
\text { K-SFM } \\
\text { (DLS) } \\
\psi\end{array}$ & $\begin{array}{l}\text { Size in } \\
\text { RPMI- } \\
\text { FCS } \\
\text { (DLS) } \Psi\end{array}$ & $\begin{array}{l}\text { Zeta } \\
\text { potential } \\
\text { K-SFM }\end{array}$ & $\begin{array}{l}\text { Zeta } \\
\text { potential } \\
\text { RPMI - } \\
\text { FCS }\end{array}$ \\
\hline NM101 & $\mathrm{TiO}_{2}$ & $\underset{\epsilon}{\text { Anatase }}$ & 9 & $4-8 / 50-100$ & $\begin{array}{l}\text { Two structures found; type } 1 \text { show agglomerates in the } \\
\qquad 50-1500 \mathrm{~nm} \text { range }\end{array}$ & 322 & none & 221 & 358 & -11.4 & -17.7 \\
\hline NM110 & $\mathrm{ZnO}$ & Zincite & 70 to $>100$ & $20-250 / 50-350$ & $\begin{array}{l}\text { Mainly } 2 \text { euhedral morphologies: } 1 \text { ) aspect ratio close to } 1 \\
\text { ( } 20-250 \mathrm{~nm} \text { range and few particles of approx. } 400 \mathrm{~nm} \text { ) } \\
\text { 2) ratio } 2 \text { to } 7.5 \text { ( } 50-350 \mathrm{~nm} \text { ). Minor amounts of particles } \\
\text { with irregular morphologies observed. }\end{array}$ & 14 & none & 393 & 453.6 & -11.5 & -13 \\
\hline NM111 & $\mathrm{ZnO}$ & Zincite & $58-93$ & $20-200 / 10-450$ & $\begin{array}{l}\text { As NM110, but with different size distributions. 1) particles } \\
\text { with aspect ratio close to } 1(\sim 90 \% \text { in the } 20-200 \mathrm{~nm} \\
\text { range); } 2) \text { particles with aspect ratio } 2 \text { to } 8.5(\sim 90 \% \text { in the } 10- \\
450 \mathrm{~nm} \text { ratio). }\end{array}$ & 18 & $\begin{array}{l}\text { Trie-othoxy- } \\
\text { capry-Isilane } 130\end{array}$ & 332 & 362.4 & -11.4 & -12.6 \\
\hline NM300 & $\mathrm{Ag}$ & $\mathrm{Ag}$ & $\begin{array}{c}7^{\lessgtr} \\
14^{ \pm} \\
<18 / 15 />100^{\#}\end{array}$ & 8-47 (av.: 17.5) & $\begin{array}{l}\text { Mainly euhedral NM; minor fractions have either elongated } \\
\text { (aspect ratio up to 5) or sub-spherical morphology }\end{array}$ & NA & none & 87 & 51.59 & -10.2 & -13.3 \\
\hline NM400 & MWCNT & - & - & $\begin{array}{c}\text { D: } 5-35 \\
\text { L: } 700-3000\end{array}$ & $\begin{array}{l}\text { Irregular entangled kinked and mostly bent MWCNT (10-20 } \\
\text { walls). Some CNTs were capped and some cases multiple } \\
\text { caps were found due to overgrowth. Fe/Co catalysts (6-9 } \\
\text { nm, average } 7.5 \mathrm{~nm} \text { ) were found inside the tubes. }\end{array}$ & 298 & none & * & * & * & * \\
\hline NM402 & MWCNT & - & - & $\begin{array}{l}\text { D: 6-20 } \\
\text { L: } 700-4000\end{array}$ & $\begin{array}{c}\text { Entangled irregular, mostly bent MWCNT (6-14 walls). } \\
\text { Some tubes were capped by unknown material. Some } \\
\text { nano-onions }(5-10 \mathrm{~nm}) \text { and amorphous carbon structures } \\
\text { mixed with Fe }(5-20 \mathrm{~nm}) \text {. Residual catalyst was observed. } \\
\text { Individual catalyst particles up to } 150 \mathrm{~nm} \text { were also } \\
\text { detected. }\end{array}$ & 225 & none & * & * & * & * \\
\hline NRCWE001 & $\mathrm{TiO}_{2}$ & Rutile $^{\S}$ & 10 & $80-400$ & Irregular euhedral particles detected by TEM & 99 & none & 349 & 337.5 & -11.6 & -14.7 \\
\hline NRCWE002 & $\mathrm{TiO}_{2}$ & Rutile & 10 & $80-400$ & Irregular euhedral particles detected by TEM & 84 & Positive charged & 314 & 378.8 & -13.2 & -12.7 \\
\hline NRCWE003 & $\mathrm{TiO}_{2}$ & Rutile & 10 & $80-400$ & Irregular euhedral particles detected by TEM & 84 & $\begin{array}{l}\text { Negative } \\
\text { charged }\end{array}$ & 384 & 423.6 & -15.3 & -13.2 \\
\hline
\end{tabular}


Table 1 Main physicochemical characteristics of engineered nanomaterials investigated - reproduced from [14] (Continued)

\begin{tabular}{|c|c|c|c|c|}
\hline NRCWE004 & $\mathrm{TiO}_{2}$ & Rutile & App. 100 & $\begin{array}{c}1-4 / 10-100 / \\
100-200 / 1000- \\
2000\end{array}$ \\
\hline
\end{tabular}

Five different particle types were identified: 1) irregular spheres, 1-4 nm (av. Diameter); 2) irregular euhedral

2000 particles, 10-100 nm (longest dimension); 3) fractal-like

structures in long chains, 100-200 nm (longest dimension):

4) big irregular polyhedral particles, 1-2 $\mu \mathrm{m}$ (longest

dimension); 5) large irregular particles with jagged

$€ 1$ percent rutile found in one of two samples analyzed.

$\$$ wet XRD in capillary tube.

f
dried samples.

\# sample with deposits.

${ }^{5} \mathrm{ca} .6 \%$ anatase was observed in one of two samples analyzed.

* Not detectable by DLS due to the very large aspect ratio.

$\psi$ Intensity based size average in biological media after $15 \mathrm{mins}$

Zincite -mineral form of $\mathrm{ZnO}$.

PDI (polydispersity index) values were under 0.45 for all given DLS values.

Abbreviations:

D, Diameter.
DLS, Dynamic Light Scattering.

ENM, Engineered nanomaterial.

L, Length.

$\mathrm{XRD}, \mathrm{X}$ ray diffraction. 
penicillin/streptomycin (termed RPMI-FCS), at $37^{\circ} \mathrm{C}$ and $5 \% \mathrm{CO}_{2}$. Two different media with varying amounts of protein (K-SFM less than 2\% proteins, RPMI-FCS $10 \%$ protein) were utilised to allow comparisons of the in vitro cytotoxicity to $\mathrm{HK}-2$ cells.

The Ag was supplied in de-ionised water (85\%) with $7 \%$ stabilizing agent (ammonium nitrate) and 8\% emulsifiers (4\% each of Polyoxyethylene Glycerol Trioleate and Tween 20). All other materials were supplied as dry powders. NMs were dispersed in MilliQ deionised water with $2 \%$ FCS. For the coated $\mathrm{ZnO}$, the particles were wetted with $0.5 \%$ vol ethanol before the addition of the dispersion media. The nanomaterials were sonicated for 16 mins without pause following the protocol developed for ENPRA [15]. Following the sonication step, all samples were immediately transferred to ice.

To ascertain the toxicity of NMs to the HK-2 cells, ten concentrations between 0.16 and $80 \mu \mathrm{g} / \mathrm{cm}^{2}$ were used (corresponding to 0.5 to $256 \mu \mathrm{g} / \mathrm{ml}$ ).

\section{WST-1 cell viability assay}

The renal cell lines were seeded in 96 well plates $10^{4}$ cells per well in $100 \mu \mathrm{l}$ of the cell culture medium and incubated for $24 \mathrm{hr}$ in K-SFM or $48 \mathrm{hr}$ with comp RPMI-FCS at $37^{\circ} \mathrm{C}$ and $5 \% \mathrm{CO}_{2}$. The following day the cells were exposed to the materials or controls for $24 \mathrm{hr}$ at $37^{\circ} \mathrm{C}, 5 \% \mathrm{CO}_{2}$. Subsequent to NM treatment, cell supernatants were collected and frozen at $-80^{\circ} \mathrm{C}$ and later used for FACS array analysis. Plates were washed twice with phosphate buffered saline (PBS), followed by the addition of $10 \mu \mathrm{l}$ of the WST-1 cell proliferation reagent and $90 \mu \mathrm{l}$ of fresh medium. Plates were then incubated for $1 \mathrm{hr}$ at $37^{\circ} \mathrm{C}, 5 \% \mathrm{CO}_{2}$. The supernatant was transferred to a fresh plate and the absorbance measured by dual wavelength spectrophotometry at $450 \mathrm{~nm}$ and 630 $\mathrm{nm}$ using a micro-plate reader.

\section{Production of IL6, IL8, TNF- $a$ and MCP-1}

The levels of human interleukin 6 (IL 6), IL8, tumour necrosis factor $\alpha$ (TNF- $\alpha)$ and monocyte chemoattractant protein 1 (MCP-1) from $\mathrm{HK}-2$ supernatants was measured using the $\mathrm{BD}^{\mathrm{TM}}$ Cytometric Bead Array cytokine Flex sets (bead based immunoassay) according to the manufacturer's instructions. A $\mathrm{BD}^{\mathrm{TM}}$ FACSArray, USA was utilised for cytokine measurement.

\section{HE oxidation}

The renal cells were seeded in 12 well plates $\left(10^{4}\right.$ cells per $\mathrm{cm}^{2}$ in $1 \mathrm{ml}$ of medium) and incubated for $48 \mathrm{hr}$ at $37^{\circ} \mathrm{C}$ and $5 \% \mathrm{CO}_{2}$. Cells were exposed to the materials or controls for $4 \mathrm{hr}$ at $37^{\circ} \mathrm{C}, 5 \% \mathrm{CO}_{2}$. The treatment was removed and the cells were washed with complete medium. Cells were then harvested with $0.05 \%$ trypsin/ EDTA and centrifuged at $300 \mathrm{~g}$ for $5 \mathrm{~min}$ before being re-suspended in phenol red free media containing $1 \mu \mathrm{M}$ of dihydroethidium (DHE) (specific for superoxide production) (Sigma, France) for $30 \mathrm{~min}$ at $37^{\circ} \mathrm{C}$ in the dark and analysed by CyAn ADP LX DakoCytomation cytometer (Beckman Coulter, France). Excitation and emission wavelengths were 488 and $620 \mathrm{~nm}$ respectively. Minimum of 10000 cells was analyzed after exclusion of cellular debris and NMs from the analysis by gating on the $620 \mathrm{~nm}$ Log versus FS area graph.

\section{Detection of DNA strand breaks in HK-2 cells}

The FPG (formamidopyrimidine [fapy] - DNA glycosylase) modified Comet assay was used to measure DNA strand breaks and specific oxidative DNA damage such as 7 , 8-dihydro-8-oxoguanine, 8-oxoadenine, fapy-guanine etc., as previously described [16]. In this study the tail moment [17] was measured using an automatic image analyser (Comet Assay IV; Perceptive Instruments, UK) connected to a fluorescence microscope. Images were captured using a stingray $(\mathrm{F}-033 \mathrm{~B} / \mathrm{C})$ black and white video camera.

Briefly, after a $4 \mathrm{hr}$ NM treatment (or positive control $60 \mu \mathrm{M}$ of $\mathrm{H}_{2} \mathrm{O}_{2}$ ), the $\mathrm{HK}-2$ cells were rinsed twice with PBS and detached using trypsin before being suspended in $5 \mathrm{ml}$ of culture medium. Cells were centrifuged for 10 mins at $250 \mathrm{~g}, 4^{\circ} \mathrm{C}$ and re-suspended at a concentration of $1.5 \times 10^{6}$ cells $/ \mathrm{ml}$ in complete medium. A $20 \mu \mathrm{l}$ volume of calculated cell suspension was added to $240 \mu \mathrm{l}$ of $0.5 \%$ low melting point agarose. Next, $125 \mu \mathrm{l}$ of the mixture was added to pre-coated slides (1.5\% agarose) in triplicate. Following 10 mins of solidification on ice, slides were lyzed overnight at $4^{\circ} \mathrm{C}$ in lysis buffer $(2.5 \mathrm{M} \mathrm{NaCl}, 100 \mathrm{mM}$ EDTA, 10 mM Tris-base, pH 10, containing 10\% DMSO and $1 \%$ TritonX-100). The slides were washed three times for 5 mins with FPG enzyme buffer (40 mM HEPES, 100 $\mathrm{mM} \mathrm{KCl}, 0.5 \mathrm{mM}$ EDTA, $0.2 \mathrm{mg} / \mathrm{ml}$ BSA - pH 8), covered with $100 \mu \mathrm{l}$ of either buffer or FPG in buffer (1:30), sealed with a cover slip and incubated for 30 mins at $37^{\circ} \mathrm{C}$. FPG cleaves DNA at locations of oxidation leading to a greater tail for cells exhibiting oxidative DNA damage [18]. All slides were then transferred into a black chilled electrophoresis tank. After alkaline unwinding ( $\mathrm{pH} 13)$ for 20 mins, electrophoresis was performed for $15 \mathrm{mins}$ at 270 $\mathrm{mA}, 24 \mathrm{~V}$. Slides were neutralized three times for 5 mins using a neutralization buffer (0.4 M TrisBase, $\mathrm{pH} 7.5)$. Before analysis, slides were dried for $10 \mathrm{mins}$ and stained with GelRed ( 2 in 10000, $40 \mu \mathrm{l}$ per slide). A total of 50 cells were analyzed per slide per experiment.

\section{Statistical analysis}

All data are expressed as mean \pm standard error of the mean. For statistical analysis, the experimental results were compared to their corresponding control values using an ANOVA with Tukey's multiple comparison. All 
statistical analysis was carried out utilizing Minitab 15. A $p$ value of $<0.05$ was considered to be significant. All experiments were repeated a minimum of three times.

\section{Results}

Characteristics of nanomaterials and exposure media

Investigated nanomaterials were characterised by a combination of analytical techniques in order to infer primary physical and chemical properties useful to understand their toxicological behaviour. A list of the measured physical and chemical properties is described (Table 1). In order to investigate if the nanomaterials behaved differently in K-SFM or RPMI-FCS, the hydrodynamic size distributions and zeta potential of the NMs dispersed in the two media was measured between a $1-128 \mu \mathrm{g} / \mathrm{ml}$ concentration range by DLS (Table 1). It is widely accepted that DLS is not a suitable method of ascertaining the size of carbon nanotubes (due to the fact that the machine measures size based on the principle that particles are spherical and well dispersed), hence we examined how the two MWCNTs behave in our two chosen media utilising light microscopy. We found that the MWCNTs agglomerated into larger clusters in the complete RPMI which contained higher levels of FCS in comparison to the K-SFM (data not shown). Our zeta potential data seems to demonstrate that these NMs have the tendency to aggregate in the media utilised in this study (Table 1).

Impact of the selected panel of NMs on HK-2 cell viability Our toxicity data show a dose dependent decrease in cell viability at $24 \mathrm{hr}$ across the entire nanomaterial panel (Table 2). The Ag and the two $\mathrm{ZnO}$ NMs were shown to be highly cytotoxic (NM $111 \mathrm{LC}_{50} 2.5 \mu \mathrm{g} / \mathrm{cm}^{2}-\mathrm{K}-\mathrm{SFM}$, $\mathrm{LC}_{50} 0.9 \mu \mathrm{g} / \mathrm{cm}^{2}$ - RPMI-FCS; NM $110 \mathrm{LC}_{50} 2.5 \mu \mathrm{g} / \mathrm{cm}^{2}-$ K-SFM, LC $501 \mu \mathrm{g} / \mathrm{cm}^{2}$ - RPMI-FCS; NM $30010 \mu \mathrm{g} / \mathrm{cm}^{2}-$
K-SFM, LC L $_{50} 4.5 \mu \mathrm{g} / \mathrm{cm}^{2}$ - RPMI-FCS) after a $24 \mathrm{hr}$ exposure. All of the $\mathrm{TiO}_{2}$ and MWCNT NMs were considered to be low toxicity materials as the $\mathrm{LC}_{50}$ was not reached after a $24 \mathrm{hr}$ exposure to the HK-2 cells at the range investigated. We observed slightly higher cytotoxicity to the cells in RPMI-FCS exposed to the Ag and $\mathrm{ZnO}$ NMs. We also investigated the toxicity of the ENPRA dispersants namely NM 300 dispersant termed (NM 300 DIS) and $0.5 \%$ ethanol in complete medium. We found no cytotoxicity of any of these dispersants to the HK-2 cells (data not shown) so we conclude that all observed toxicity is due to exposure to the NMs investigated. $\mathrm{LC}_{20}$ are shown as these values were utilised for the FPG modified comet assay (Table 2).

\section{Cytokine secretion by HK-2 cells following exposure to the panel of NMs}

Changes in cytokine production as a consequence of NM exposure were assessed within the supernatant of exposed renal cells and quantified via FACSArray. We found a dose dependent (exposure to sub-lethal concentrations of the NMs) increase in the levels of IL8 and IL6 from the kidney cells with statistical significance being reached at the higher concentrations following exposure to nine of the ten nanomaterials $\left(\mathrm{TiO}_{2}-\mathrm{NM}\right.$ 101 being the exception) (Figure 1J). Additionally we found no change in the levels of MCP-1 or TNF- $\alpha$ secreted from the HK-2 cells following the $24 \mathrm{hr}$ exposure to any of the selected NMs (data not shown).

\section{HE Oxidation}

Hydroethidium is the chemically reduced form of the commonly used DNA intercalating dye ethidium bromide [19]. This reduced dye is therefore useful for detection of oxidative activities in viable intact cells. Only once it is internalized and dehydrogenated (oxidized) to

Table 2 Cytotoxicity following exposure of the HK-2 cells in two different media to a panel of engineered nanomaterials

\begin{tabular}{|c|c|c|c|c|}
\hline \multirow[t]{2}{*}{ NM } & \multicolumn{2}{|c|}{ K-SFM } & \multicolumn{2}{|c|}{ RPMI-FCS } \\
\hline & $\mathrm{LC}_{20}$ & $\mathrm{LC}_{50}$ & $\mathrm{LC}_{20}$ & $\mathrm{LC}_{50}$ \\
\hline NM 111 & $0.8 \mu \mathrm{g} / \mathrm{cm}^{2}$ & $2.5 \mu \mathrm{g} / \mathrm{cm}^{2}$ & $0.5 \mu \mathrm{g} / \mathrm{cm}^{2}$ & $0.9 \mu \mathrm{g} / \mathrm{cm}^{2}$ \\
\hline NM 110 & $0.64 \mu \mathrm{g} / \mathrm{cm}^{2}$ & $2.5 \mu \mathrm{g} / \mathrm{cm}^{2}$ & $0.64 \mu \mathrm{g} / \mathrm{cm}^{2}$ & $1 \mu \mathrm{g} / \mathrm{cm}^{2}$ \\
\hline NM 300 & $1.25 \mu \mathrm{g} / \mathrm{cm}^{2}$ & $10 \mu \mathrm{g} / \mathrm{cm}^{2}$ & $1.25 \mu \mathrm{g} / \mathrm{cm}^{2}$ & $4.5 \mu \mathrm{g} / \mathrm{cm}^{2}$ \\
\hline NM 400 & $2.5 \mu \mathrm{g} / \mathrm{cm}^{2}$ & Not reached up to $80 \mu \mathrm{g} / \mathrm{cm}^{2}$ & $20 \mu \mathrm{g} / \mathrm{cm}^{2}$ & Not reached up to $80 \mathrm{\mu g} / \mathrm{cm}^{2}$ \\
\hline NM 402 & $4.5 \mu \mathrm{g} / \mathrm{cm}^{2}$ & Not reached up to $80 \mu \mathrm{g} / \mathrm{cm}^{2}$ & $20 \mu \mathrm{g} / \mathrm{cm}^{2}$ & Not reached up to $80 \mathrm{\mu g} / \mathrm{cm}^{2}$ \\
\hline NRCWE 002 & $20 \mu \mathrm{g} / \mathrm{cm}^{2}$ & Not reached up to $80 \mu \mathrm{g} / \mathrm{cm}^{2}$ & Not reached up to $80 \mu \mathrm{g} / \mathrm{cm}^{2}$ & Not reached up to $80 \mathrm{\mu g} / \mathrm{cm}^{2}$ \\
\hline NRCWE 001 & $40 \mu \mathrm{g} / \mathrm{cm}^{2}$ & Not reached up to $80 \mu \mathrm{g} / \mathrm{cm}^{2}$ & Not reached up to $80 \mu \mathrm{g} / \mathrm{cm}^{2}$ & Not reached up to $80 \mu \mathrm{g} / \mathrm{cm}^{2}$ \\
\hline NRCWE 004 & $40 \mu \mathrm{g} / \mathrm{cm}^{2}$ & Not reached up to $80 \mu \mathrm{g} / \mathrm{cm}^{2}$ & Not reached up to $80 \mu \mathrm{g} / \mathrm{cm}^{2}$ & Not reached up to $80 \mathrm{\mu g} / \mathrm{cm}^{2}$ \\
\hline NRCWE 003 & $60 \mu \mathrm{g} / \mathrm{cm}^{2}$ & Not reached up to $80 \mu \mathrm{g} / \mathrm{cm}^{2}$ & Not reached up to $80 \mu \mathrm{g} / \mathrm{cm}^{2}$ & Not reached up to $80 \mathrm{\mu g} / \mathrm{cm}^{2}$ \\
\hline NM 101 & Not reached up to $80 \mu \mathrm{g} / \mathrm{cm}^{2}$ & Not reached up to $80 \mu \mathrm{g} / \mathrm{cm}^{2}$ & Not reached up to $80 \mu \mathrm{g} / \mathrm{cm}^{2}$ & $80 \mu \mathrm{g} / \mathrm{cm}^{2}$ \\
\hline
\end{tabular}

The cells were exposed to the NM for $24 \mathrm{hr}$ with cytotoxicity measured via WST-1 (NMs ranked in order of cytotoxicity to HK-2 cells - high to low). 


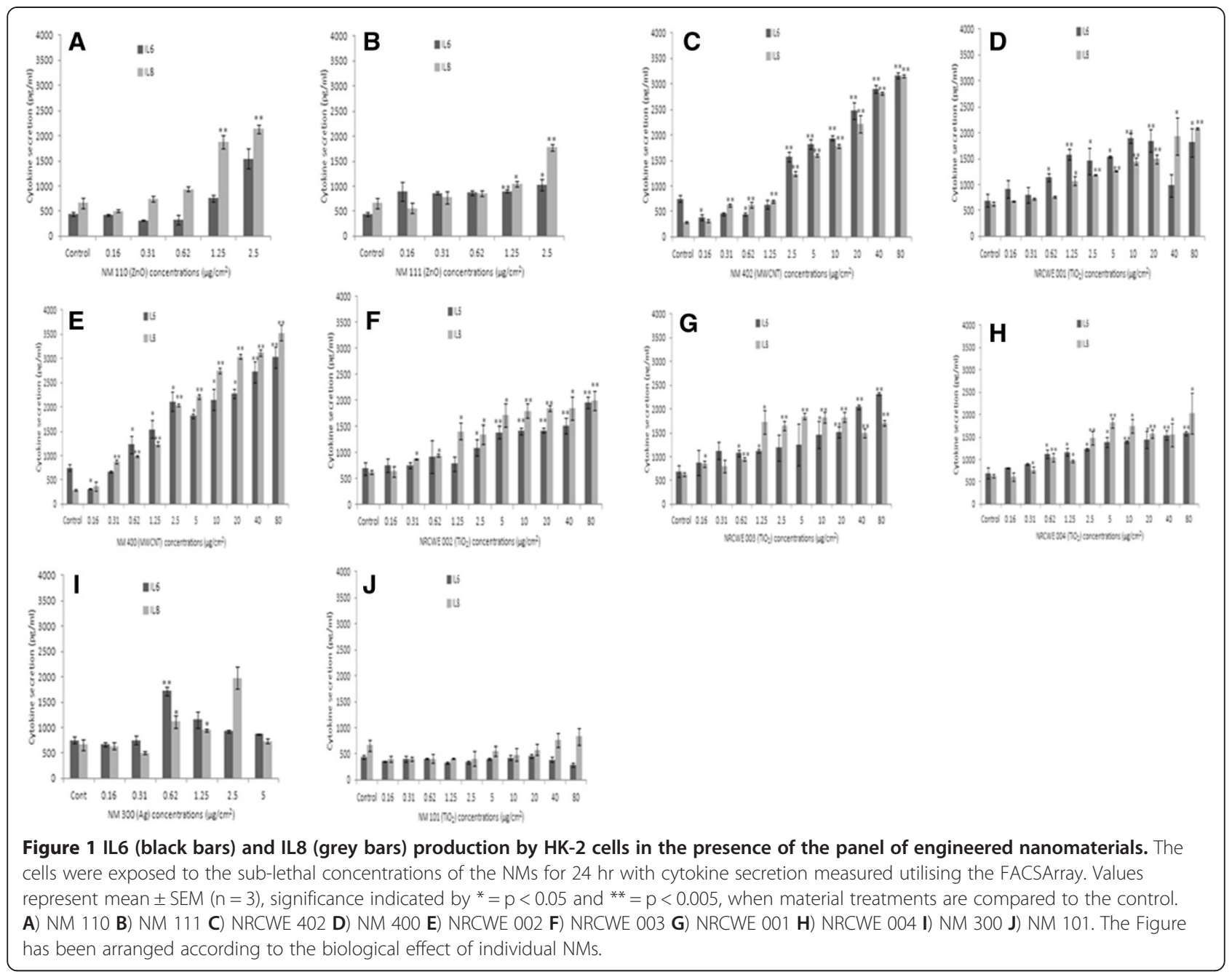

ethidium, it can intercalate into DNA. Normally due to their compromised membranes, only dead cells are typically labelled by ethidium bromide when it selectively binds to DNA. However HE is a neutral probe and is able to penetrate the cell membrane of live cells, staining their cytoplasm blue as well as the chromatin/nucleus of living cells red. We noted a significant increase in HE positive cells following exposure to $\mathrm{Ag}$ and $\mathrm{ZnO} \mathrm{NMs}$ (Figure 2A and B). A very small yet significant increase was also observed to all the $\mathrm{TiO}_{2} \mathrm{NM}$ with the exception of NRCWE 003 (Figure 2C). However no change in intracellular reactive oxygen species was noted following exposure to either of the MWCNTs (Figure 2D).

\section{DNA damage in the HK-2 cells}

In order to investigate the possible DNA damage caused by the panel of nanomaterials, HK-2 cells were exposed to the NMs for $4 \mathrm{hr}$. In this study we chose the $\mathrm{LC}_{20}$ value for each individual $\mathrm{NM}$ plus one concentration above $\left(2 \times \mathrm{LC}_{20}\right)$ and one below $\left(0.5 \times \mathrm{LC}_{20}\right)$. For the $\mathrm{TiO}_{2}$ NMs (NM 101, NRCWE 001 and NRCWE 002) were an $\mathrm{LC}_{20}$ was not reached the three highest concentrations were utilised. We observed that DNA damage was most evident following exposure to NM 300 (Ag) and NRCWE 002 (positively charged $\mathrm{TiO}_{2}$ ) (Figure 3A, B). We also noted a small but significant increase in the percentage of tail DNA following exposure to five of the other eight NMs investigated $\left(\mathrm{ZnO}-\mathrm{NM} 111, \mathrm{TiO}_{2}\right.$ NRCWE 001 and $003 \mathrm{TiO}_{2}$ NMs being the exception) (Figure 3H, I and J).

\section{Discussion}

This study was conducted as part of a large consortium (FP7 project - ENPRA) to investigate the hazards associated with a wide range of nanomaterials on a variety of target systems for risk assessment. For this reason, the wide dose response range was used in order to allow calculation of values such as $\mathrm{LC}_{50}$ for comparisons between different materials and cell target types both in vitro and in vivo. For this particular manuscript kidneys were the target of interest. 


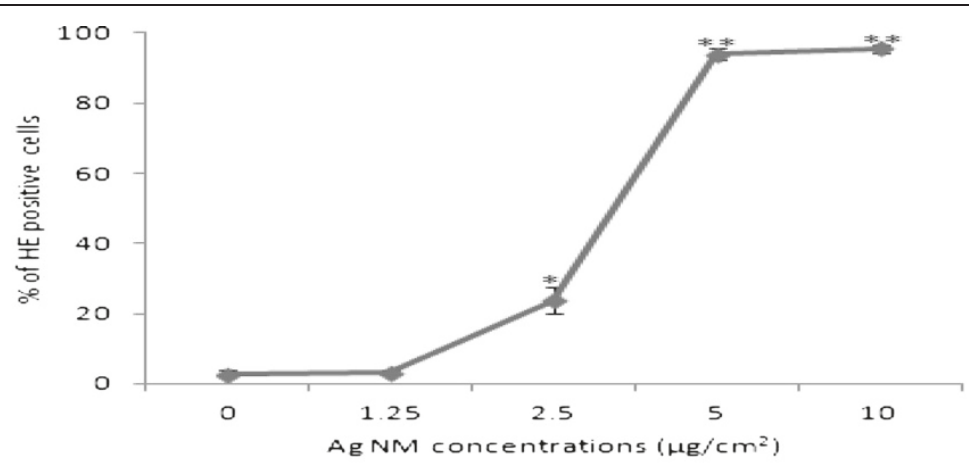

A
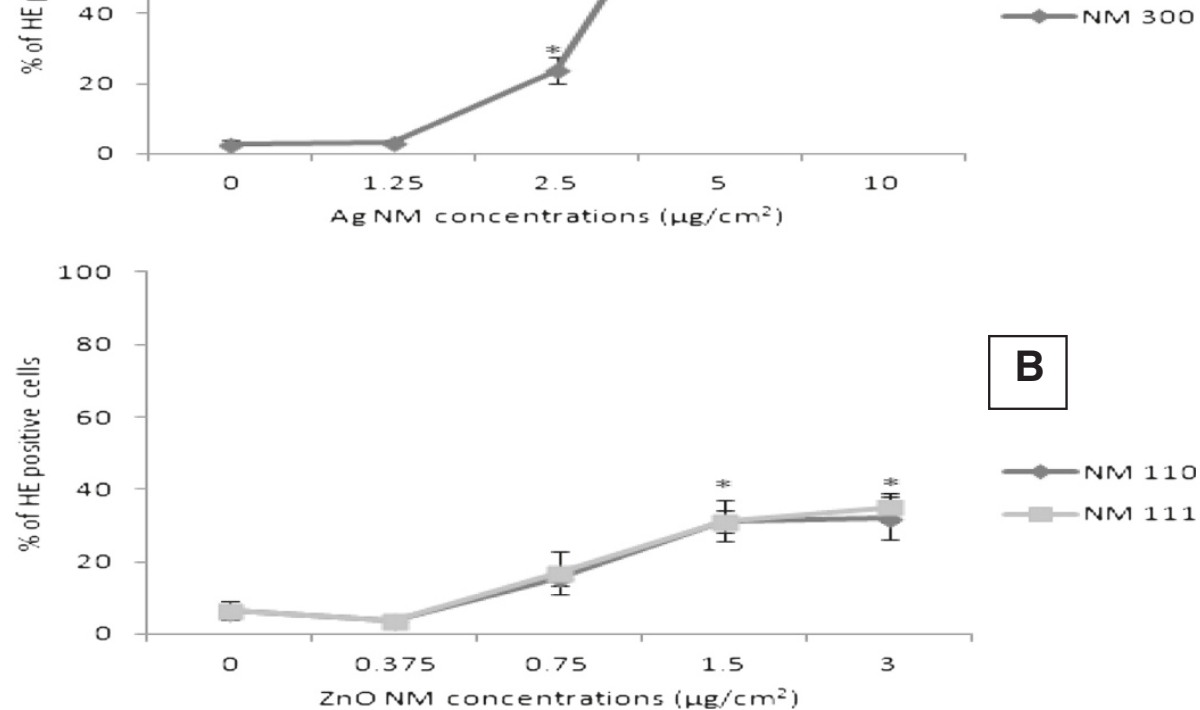

B
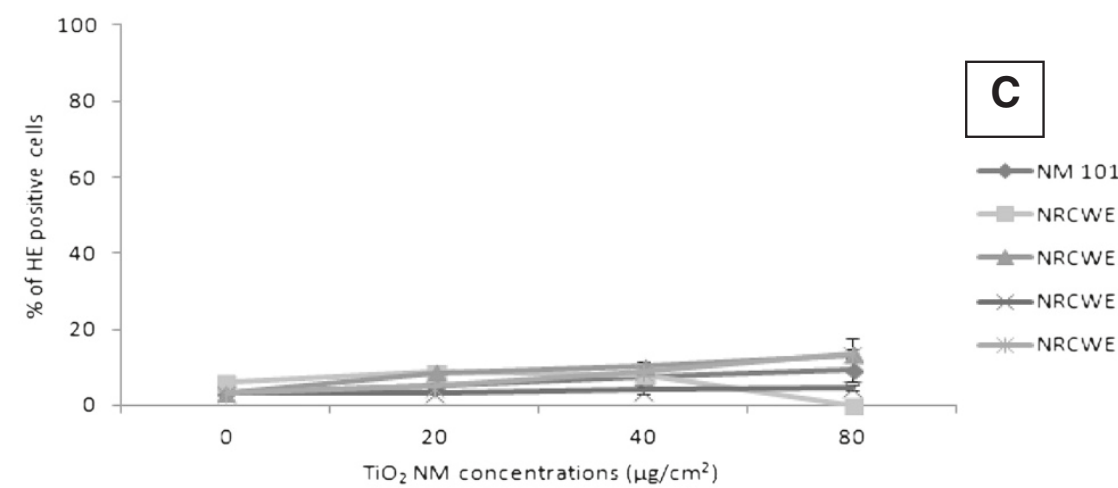

- NRCWE 001

-NRCWE 002

$\longrightarrow$ NRCWE 003

NRCWE 004

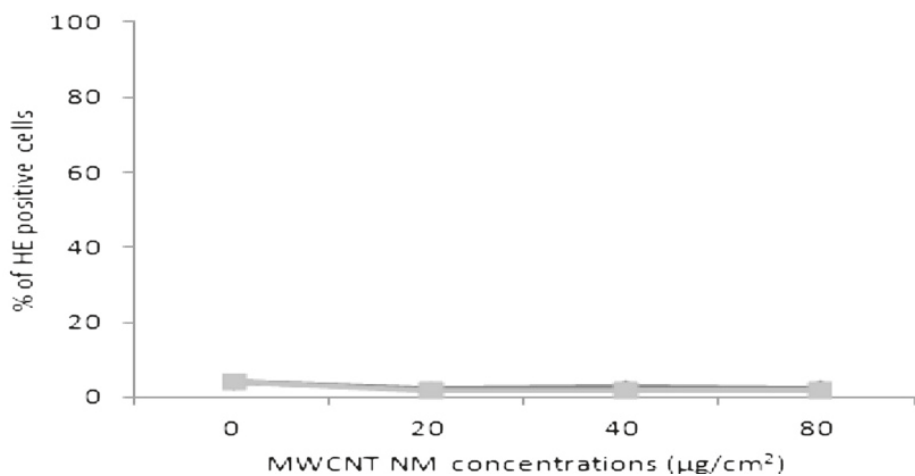

D

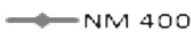

- NM 402

MWCNT NM concentrations $\left(\mu \mathrm{g} / \mathrm{cm}^{2}\right)$

Figure 2 Intracellular ROS production following exposure of the HK-2 cells to the panel of engineered nanomaterials. The cells were exposed to the NM for $4 \mathrm{hr}$ with oxidative stress measured via HE oxidation by flow cytometry. Values represent mean \pm SEM $(n=6) \mathbf{A})$ Ag $-\mathrm{NM}$ 300 B) ZnO - NM 110 and NM 111 C) $\mathrm{TiO}_{2}$ - NM 101, NRCWE 001, 002, 003 and 004 D) MWCNT - NM 400 and NM 402. 


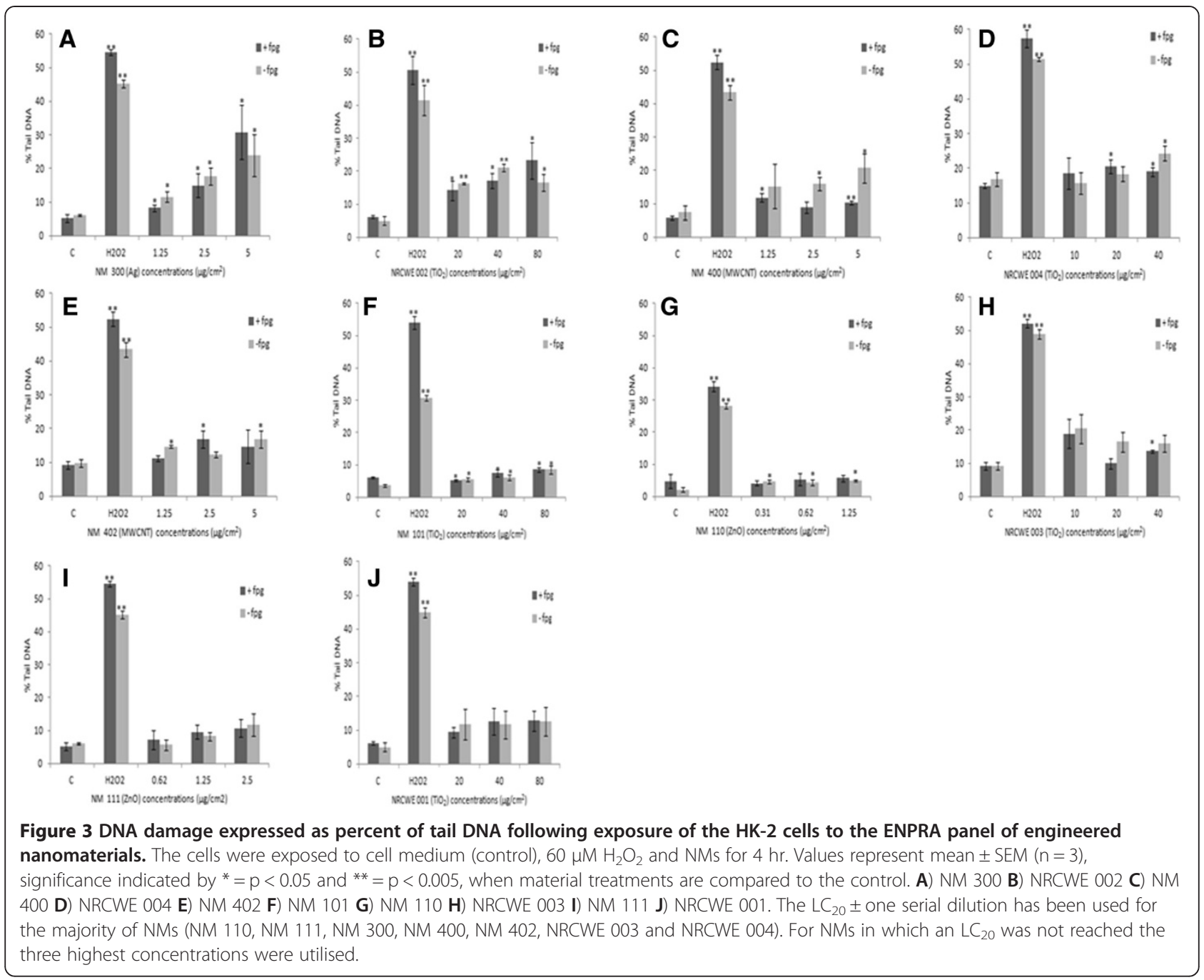

To date human kidneys have received relatively little attention in terms of a nanotoxicological studies. Due to high blood supply level and ability to concentrate toxins, this organ could be potentially affected by any nanomaterial that reaches the circulatory system. During active and passive transport of molecules during reabsorption across the nephral proximal tubule, this part of the nephron may be at high risk of potential damage from NMs. It has been shown previously that the proximal renal tubule is more susceptible to gold NM toxicity than the distal tubule [20]. In a recent study it was shown that a high concentration of orally administrated Ag NMs accumulated in kidney tissues at a higher wet mass than any other organ [21]. This observation suggests that kidneys are important organs in clearing the NMs from the mammalian system and at potential risk of being damaged by NM exposure. Hence we have chosen an immortalized proximal tubule epithelial cell line from adult human kidney (HK-2) as a well differentiated cell line representing an alternative to primary kidney cells [22]. This study has focused on the impacts of the investigated panel of nanomaterials on cell cytotoxicity, pro-inflammatory cytokine production, intracellular ROS and DNA damage.

Here we have shown that following acute in vitro exposure of the cells to the panel of the NMs, they can be segregated into a low $\left(\mathrm{TiO}_{2}\right.$ and MWCNT) and a high toxicity group (Ag, and $\mathrm{ZnO}$ ) (Table 1 ). This complements our previous data for a hepatocyte cell line [14] and primary human hepatocytes [23]. We also observed slightly higher cytotoxicity (not significant) to the cells in RPMI-FCS exposed to the Ag and ZnO NMs (higher amounts of protein within the media compared to the K-SFM) utilised in this study. One theory offering an explanation for this could be that the serum interaction with the NMs might make the materials more bioavailable to the cells. It is also possible that the cells might be healthier in the K-SFM compared to RPMI with FCS under the conditions in this study.

We noted that the Ag NM (NM 300) was highly toxic to the HK-2 cells $\left(\mathrm{LC}_{50}\right.$ between $\left.4.5-10 \mu \mathrm{g} / \mathrm{cm}^{2}\right)$. To 
our knowledge no study has investigated the toxicity of Ag nanomaterials and human kidney cells in vitro however a number of studies have demonstrated that $\mathrm{Ag}$ NMs can be highly toxic in other organs and systems both in vivo and in vitro [14,24,25]. Oxidative stress is often proposed as a mechanism of toxicity $[25,26]$. Our HE oxidation data show an increase in intracellular ROS levels following exposure to the NM 300. However a note caution is required as this increase in $\mathrm{HE}$ positive cells could be due to cell death. We do not believe this to be the case predominately for two reasons. Firstly, only sub-lethal doses were utilised in these experiments. Secondly, the cells were only exposed to NMs for $4 \mathrm{hr}$ in these experiments with the aim of identifying the mechanisms underlying the cytotoxicity. Furthermore we noted that there was an increase in IL6 and IL8 levels following exposure of the cells to the Ag NMs (highest release at intermediated doses - suggesting cytotoxicity (cell death) inhibits cytokine production at the highest doses), as well as a significant increase in genotoxicity following exposure to sub-lethal concentrations of the nanomaterial. This indicates that Ag NMs are highly genotoxic to human kidney cells. So far a number of other studies have confirmed dose dependent DNA damage after Ag NM treatment to a liver cell line [27] or genotoxicity in testicular cells [28].

Next we have shown that the two $\mathrm{ZnO} \mathrm{NMs}$ were highly toxic (with the $\mathrm{LC}_{50}$ around $0.9-2.5 \mu \mathrm{g} / \mathrm{cm}^{2}$ ) to the renal cells. Our findings are similar to a previous study in which HK-2 cells were shown to be highly susceptible to exposure to $\mathrm{ZnO} \mathrm{NMs}\left(\mathrm{LC}_{50}-2.4 \mu \mathrm{g} / \mathrm{cm}^{2}\right)$ [29]. The toxicity was associated with increased intracellular ROS production which is very similar to our findings here [29]. Notably, exposure to the two zinc oxide NMs showed only a small increase in percentage of tail damage. It is possible that the $4 \mathrm{hr}$ exposure time for genotoxicity was not sufficient to cause larger effects from the two $\mathrm{ZnO}$ NMs in this study. Next, we noted a dose dependant increase in IL6 and IL8 secretion from the cells following NM exposure. It has been shown previously that there is an increase of these pro-inflammatory mediators from the kidney following exposure to various antigens [30,31]. In a similar theme exposure of human embryonic kidney cell line HEK 293 to 100 nm ZnO NMs resulted in up-regulation of IL6 and IL8 genes from the cells in vitro [32].

We had previously shown that the two $\mathrm{ZnO} \mathrm{NMs}$ used in this study are highly soluble (40-50\%) while less than 1\% of $\mathrm{Ag}$ (NM 300) was soluble after $24 \mathrm{hr}$ of incubation in complete medium [14]. Therefore there is a real possibility that the high cytotoxicity of the two $\mathrm{ZnO}$ materials are in part due to the release of ions, with this scenario being less likely following exposure to the Ag NMs.
It has been shown previously that in sufficient doses $\mathrm{TiO}_{2}$ can cause damage to cells and tissue [14,33,34]. Furthermore other studies have shown that after translocation from the primary site of exposure, the NMs can induce oxidative stress - mediated toxicity in many cell types by producing large amounts of free radicals $[12,35,36]$. In this study we found all five $\mathrm{TiO}_{2}$ were of relatively low cytotoxicity to the $\mathrm{HK}-2$ cells $\left(\mathrm{LC}_{50}\right.$ was not reached in the presence of any of the NMs up to 80 $\mu \mathrm{g} / \mathrm{cm}^{2}$ ) with only small increases of oxidative stress presenting cells following exposure to four of the five $\mathrm{TiO}_{2}$ NMs. Our findings are similar to a previous study in which exposure of HK-2 cells to a $12 \mathrm{~nm} \mathrm{TiO}_{2}$ resulted in low toxicity [29]. Similarly, in a study using Caco2 cells it was found that there was low cytotoxicity following $24 \mathrm{hr}$ exposure to $\mathrm{TiO}_{2}$ NMs [35]. In addition the data presented here indicate that relatively high $\mathrm{TiO}_{2}$ exposure concentrations can induce production of the pro-inflammatory cytokine IL6 and IL8. In a recent study exposure of mice to $6 \mathrm{~nm} \mathrm{TiO}_{2} \mathrm{NM}$ via an intragastric route promoted the expression of IL2, IL4, IL6, IL8, IL10, IL18, IL1- $\beta$, TGF- $\beta$ and IFN- $\gamma$ from the kidney [37]. Furthermore exposure of C3A cell line in vitro also resulted in IL8 secretion at high $\mathrm{TiO}_{2}$ concentrations [14,38].

We show a significant increase in genotoxicity following a $4 \mathrm{hr}$ exposure to two of the five $\mathrm{TiO}_{2} \mathrm{NMs}$ investigated in this study (NRCWE 002 and NRCWE 004 - most notable following exposure to the positively charged $\mathrm{TiO}_{2} \mathrm{NMs}$ ). One possible explanation for this could be that the positively charged NMs enter cells utilising faster and more effective pathways (fast attachment to cell membrane and ingestion) than their neutral and negative counterparts [39-41]. Overall our findings are similar to a recent study in which exposure of Cos-1 monkey kidney fibroblasts to $\mathrm{TiO}_{2}$ NMs resulted in significant DNA damage as measured via the comet assay [42].

We found that the MWCNTs tested were relatively non-toxic to the HK-2 cells at the times and concentrations tested. The toxicity of MWCNTs is widely documented, with adverse effects observed in pulmonary [34], hepatic [14], renal [43], dermal cells [44] as well as monocyte [45] and macrophage cells [46]. It has been shown that exposure of NRK-52E cells (an in vitro renal model) to MWCNT resulted in low toxicity $\left(\mathrm{LC}_{25}\right.$ following $24 \mathrm{hr}$ exposure) [47] which is similar to our findings in this study. Exposure of the HK-2 cells to the two MWCNTs in this study resulted in a dose dependant increase in both IL6 and IL8 following a $24 \mathrm{hr}$ exposure. Our findings are similar to a recent study in which exposure of HEK 293 cells to two types of MWCNTs (80 and $150 \mathrm{~nm}$ ) resulted in increased production of IL8 [48]. The HE oxidation assay showed no intracellular ROS following exposure to either of two MWCNTs. This is contradictory to findings from Reddy 
and colleagues in which cytotoxicity was associated with oxidative stress [48]. Finally we show that short term ( $4 \mathrm{hr}$ ) exposure of the HK-2 cells to the two carbon nanotubes at sub-lethal concentrations resulted in significant DNA damage. Barillet et al. also witnessed small but significant genotoxicity following exposure of NRK52E cells to $100 \mathrm{~nm}$ MWCNT which is similar to our findings in this study [43]. In another study exposure of lung A549 cells for $24 \mathrm{hr}$ to $-\mathrm{OH}$ functionalized and pristine MWCNTs resulted in a concentrationdependent increase of direct DNA damage [49]. Similarly A549 cells exposed to MWCNTs for $24 \mathrm{hr}$ resulted in an induction of direct DNA with statistical significance reached at $10 \mu \mathrm{g} / \mathrm{ml}$ [50].

No TNF- $\alpha$ or MCP-1 production was observed following exposure to the ENPRA panel of NMs. It has been shown that under certain disease models that kidney cells produce TNF- $\alpha$ [51] and MCP-1 [52,53]. Here we show that exposure to these particular nanomaterials even at very high (in some cases cytotoxic) doses are not sufficient for MCP-1 or TNF- $\alpha$ secretion from the cells.

Overall this study emphasises the importance of the use of sub-lethal NM concentrations in particular with regards to mechanistic studies - otherwise conclusions about cause and effect and the mechanism of action can be misleading or completely missed. It is very possible that low toxicity nanomaterials may still possess sublethal effects of toxicological consequence.

\section{Conclusions}

In conclusion, this in vitro renal model demonstrated that $\mathrm{ZnO}$ and $\mathrm{Ag} \mathrm{NMs}$ were consistently more potent with respect to cytotoxicity, cytokine production (IL6 and IL8) and intracellular reactive oxygen species production. In comparison the MWCNT and $\mathrm{TiO}_{2}$ nanomaterials investigated revealed relatively lower toxicity. We noted that short term sub-lethal exposure to seven of the ten nanomaterials resulted in DNA damage to the cells (most evident following exposure to the $\mathrm{Ag}$ and the positively charged $\mathrm{TiO}_{2}$ NMs). Studies conducted by project partners are utilising other target cells such as macrophages, lung epithelial cells, fibroblasts, endothelial cells and hepatocytes. In vivo studies are also being conducted for comparison with in vitro models. All of this data will be combined into a database to be used in risk assessment.

\section{Competing interests}

The authors declare that they are no competing interests.

\section{Authors' contributions}

AK, SV, KM and LAA have carried out the experiments within this study. SB, $B K G, A B S$ and VS have all been heavily involved in the preparation and revision of the manuscript. All authors have read and approved the final manuscript.

\section{Acknowledgements}

The authors are grateful to colleagues at Heriot-Watt University in particular Dr David Brown. Thanks to Nicole Boggetto (Platform ImagoSeine: cytométrie en flux, microscopie électronique, microscopie photonique, IJM, University Paris Diderot, UMR 7592 CNRS) for technical help.

\section{Funding}

This work has been financially supported by the European seventh framework programme co-operation [Grant code - NMP4-SL-2009-228789].

\section{Author details}

${ }^{1}$ Heriot-Watt University, School of Life Sciences, John Muir building, Edinburgh EH14 4AS, UK. ${ }^{2}$ Laboratoire Biologie Fonctionnelle et Adaptative, Equipe Réponses Moléculaires et Cellulaires aux Xénobiotiques, Université Paris Diderot-Paris 7, 5 rue Thomas Mann, 75 205, Paris cedex 13, France.

Received: 28 August 2012 Accepted: 17 April 2013

Published: 25 April 2013

\section{References}

1. Buzea C, Pacheco II, Robbie K: Nanomaterials and nanoparticles: sources and toxicity. Biointerpahses 2007, 2:18-67.

2. Edwards-Jones $\mathrm{V}$ : The benefits of silver in hygiene, personal care and healthcare. Lett Appl Microbiol 2009, 49:147-152.

3. Tetley TD: Health effects of nanomaterials. Bionanotechnol 2007, 35:527-531.

4. Hoet PHM, Hohlfeld IB, Salata O: Nanoparticles - known and unknown health risks. J Nanobiotechnol 2004, 2:12-27.

5. Papp T, Schiffmann D, Weiss D, Castronova V, Vallyathan V, Rahman Q: Human health implications of nonmaterial exposure. Nanotoxicology 2008, 2:9-27.

6. Maynard AD: Nanoparticle safety - A perspective from the United States. Issues in Environ Sci Technol 2007, 24:118-131.

7. Semmler-Behnke M, Wolfgang KG, Lipka J, Fertsch S, Wenk A, Takeneka S, Schmid G, Brandau W: Bio-distribution of 1.4 and $18 \mathrm{~nm}$ gold particles in rats. Small 2008, 12:2108-2111.

8. Yeh TK, Chen JK, Lin CH, Yang MH, Yang CS, Chou Fl, Peir JJ, Wang MY, Chang WH, Tsai MH, Tsai HT, Lin PP: Kinetics and tissue distributions of neutron-activated zinc oxide nanoparticles and zinc nitrate in mice: effects of size and particulate nature. Nanotechnology 2012, 8. online access.

9. Eisner C, Ow H, Yang TX, Jia ZJ, Dimitriadis E, Li LL, Wang K, Briggs J, Levine M, Schnermann J, Espey MG: Measurement of plasma volume using fluorescent silica-based nanoparticles. J Appl Physiol 2012, 112:681-687.

10. Roberts RG, Louden JD, Goodship THJ: An assessment of the methods available to determine nutritional equilibrium in patients with chronic and renal failure. Nephrol Dial Transplant 2000, 15:1906-1908.

11. L'Azou B, Jorly J, On D, Sellier E, Moisan F, Fluery-Feith J, Cambar J, Brochard $P$, Ohayon-Courtes $C$ : In vitro effects of nanoparticles on renal cells. Part Fibre Toxicol 2008, 5:22.

12. Wang JJ, Sanderson BJ, Wang H: Cyto- and genotoxicity of ultrafine $\mathrm{TiO}_{2}$ particles in cultured human lymphoblastoid cells. Mutat Res 2007, 628:99-106.

13. Cartiera MS, Johnson KM, Rajendran V, Caplan MJ: The uptake and intracellular fate of PGLA nanoparticles in epithelial cells. Biomaterials 2009, 30:2790-2798.

14. Kermanizadeh A, Pojana G, Gaiser BK, Birkedal R, Bilaničová D, Wallin H, Jensen KA, Sellergren B, Hutchison GR, Marcomini A, Stone V: In vitro assessment of engineered nanomaterials using C3A cells: cytotoxicity, pro-inflammatory cytokines and function markers. Nanotoxicology 2012. doi:10.3109/17435390.2011.653416.

15. Jacobsen NR, Pojano G, Wallin H, Jensen KA: Nanomaterial dispersion protocol for toxicological studies in ENPRA. Internal ENPRA Project Report. The National Research Centre for the Working Environment; 2010. available on request.

16. Speit G, Schütz P, Bonzheim I, Trenz K, Hoffmann H: Sensitivity of the FPG protein towards alkylation damage in the comet assay. Toxicol Lett 2004 146:151-158.

17. Wilklund SJ, Agurelli E: Aspects of design and statistical analysis in the Comet assay. Mutagenesis 2003, 2003(18):167-175.

18. Sidorkina OM, Laval J: Role of lysine-57 in the catalytic activities of Escherichia coli formamidopyrimidine-DNA glycosylase (Fpg protein). Nucleic Acids Res 1998, 26:5351-5357. 
19. Kalyanaraman B: Oxidative chemistry of florescent dyes: implications in the detection of reactive oxygen and nitrogen species. Biochem Soc Trans 2011, 39:1221-1225.

20. Abdelhalim MAK, Jarrar BM: The appearance of renal cells cytoplasm degeneration and nuclear destruction might be an indication of GNPs toxicity. Lipids Health Dis 2011, 10:147-153.

21. Kim YS, Song MY, Park JD, Song KS, Ryu HR, Chung YH, Chang HK, Lee JH, Oh KH, Kelman BJ, Hwang IK, Yu IJ: Subchronic oral toxicity of silver nanoparticles. Part Fibre Toxicol 2010, 7:20-31.

22. Ryan MJ, Johnson G, Kirk J, Fuerstenberg SM, Zager RA, Torok-Storb B: HK-2: an immortalized proximal tubule epithelial cell line from normal adult human kidney. Kidney Int 1994, 45:48-57.

23. Kermanizadeh A, Gaiser BK, Ward MB, Stone V: Primary human hepatocytes vs. hepatic cell line - assessing their suitability for in vitro nanotoxicology. Nanotoxicology 2012. doi:10.3109/17435390.2012.734341.

24. Gaiser BK, Fernandes TF, Jepson MA, Lead JR, Tylor CR, Baalousha M, Biswas A, Britton GJ, Cole PA, Johnston BD, Ju-Nam Y, Rosenkranz P, Scown TM, Stone $\mathrm{V}$ : Interspecies comparison on the uptake and toxicity of silver cerium dioxide nanoparticles. Environ Toxicol Chem 2012, 31:144-154.

25. Kim HR, Kim MJ, Lee SY, Oh SM, Chung KH: Genotoxic effects of silver nanoparticles stimulated by oxidative stress in human bronchial epithelial (BEAS-2B) cells. Mutat Res-Gen Toxicol Environ Mutagen 2011, 726:129-135.

26. Piao MJ, Kang KA, Lee IK, Kim HS, Kim S, Choi JY, Choi J, Hyun JW: Silver nanoparticles induce oxidative cell damage in human liver cells through inhibition of reduced glutathione and induction of mitochondrial involved apoptosis. Toxicol Lett 2011, 201:92-100.

27. Kermanizadeh A, Gaiser BK, Hutchison GR, Stone V: An in vitro liver model accessing oxidative stress and genotoxicity following exposure of hepatocytes to a panel of engineered nanoparticles. Part Fibre Toxicol 2012, 9:28. doi:10.1186/1743-8977-9-28

28. Asare N, Instanes C, Sandberg WJ, Refsnes M, Schwarze P, Kruszewski M, Brunborg G: Cytotoxic and genotoxic effects of silver nanoparticles in testicular cells. Toxicology 2012, 291:65-72.

29. Pujalté I, Passagne I, Brouillaud B, Tréguer M, Durand E, Ohayon-Courtès C, L'Azou B: Cytotoxicity and oxidative stress induced by different metallic nanoparticles on human kidney cells. Part Fibre Toxicol 2011, 8:10-26.

30. Dudas PL, Sague SL, Elloso MM, Farrell FX: Proinflammtory/Profibiotc effects of interlukin 17A on human proximal tubule epithelium. Nephron Exp Nephrol 2011, 117:114-123.

31. Shing CM, Adams MJ, Fassett RG, Coombes JS: Nutritional compounds influence tissue factor expression and inflammation of chronic kidney patients in vitro. Nutrition 2011, 27:967-972.

32. Dua P, Chaudhari KN, Lee CH, Chaudhari NK, Hong SW, Yu JS, Kim S, Lee DK: Evaluation of toxicity and gene expression changes triggered by oxide nanoparticles. Bull Korean Chem Soc 2011, 32:2051-2057.

33. Hu RP, Zheng L, Zhang T, Gao GD, Cui YL, Cheng Z, Cheng J, Hong MM, Tang M, Hong FS: Molecular mechanism of hippocampal apoptosis of mice following exposure to titanium dioxide nanoparticles. $J$ Hazard Mater 2011, 191:32-40.

34. Ji Z, Zhang D, Li L, Shen X, Deng X, Dong L, Wu M, Liu Y: The hepatotoxicity of multi-walled carbon nanotubes in mice. Nanotechnology 2009, 20:445101.

35. Jin CY, Zhu BS, Wang XF, Lu QH: Cytotoxicity of Titanium dioxide nanoparticles in mouse fibroblast cells. Chem Res Toxicol 2008, 21:1871-1877.

36. Kang SJ, Kim BM, Lee YJ, Chung HW: Titanium dioxide nanoparticles trigger p53-mediated damage response in peripheral blood lymphocytes. Environ Mol Mutagen 2008, 49:399-405.

37. Gui S, Zhang Z, Zheng L, Cui Y, Liu X, Li N, Sang X, Sun Q, Gao G, Cheng Z, Wang $L$, Tang M, Hong F: Molecular mechanism of kidney injury of mice caused by exposure to titanium dioxide nanoparticles. $J$ Hazard Mater 2011, 195:365-370

38. Monteiller C, Tran L, MacNee W, Faux S, Jones A, Miller B, Donaldson K: The pro-inflammatory effects of low toxicity low solubility particles, nanoparticles and fine particles, on epithelial cells in vitro: the role of surface area. Occup Environ Med 2007, 64:609-615.

39. Anvizo RR, Miranda OR, Thompson MA, Pabelick CM, Bhattacharya R, Robertson JD, Rotello VM, Prakash YS, Mukherjee P: Effects of nanoparticle surface charge at the plasma membrane and beyond. Nano Lett 2010, 10:2543-2548.

40. Schweiger C, Hartmann R, Zhang F, Parak WJ, Kissel TH, Gil PR: Quantification of the internalization patterns of superparamagnetic iron oxide nanoparticles with opposite charge. J Nanobiotechnology 2012, 10:28.
41. Verma A, Stellacci F: Effects of surface properties on nanoparticle-cell interactions. Small 2009, 6:12-21.

42. Magdolenova Z, Bilanicova D, Pojana G, Fjellsbo LM, Hudecova A, Hasplove K, Marcomini A, Dusinska M: Impact of agglomeration and different dispersions of titanium dioxide nanoparticles on the human related in vitro cytotoxicity and genotoxicity. J Environ Monit 2012, 14:455-464.

43. Barillet S, Simon-Deckers A, Herlin-Boime N, Mayne-L'Hermite M, Reynaud C, Cassio D, Gouget B, Carriere M: Toxicological consequences of $\mathrm{TiO}_{2}, \mathrm{SiC}$ nanoparticles and multi-walled carbon nanotubes exposure in several mammalian cell types: an in vitro study. J Nanopart Res 2010, 12:61-73.

44. Kishore AS, Surekha P, Murthy PB: Assessment of the dermal and ocular irritation potential of multi-walled carbon nanotubes by using in vitro and in vivo methods. Toxicol Lett 2009, 191:268-274.

45. De Nicola M, Nuccitelli S, Gattia DM, Traversa E, Magrini A, Bergamaschi A, Ghibelli L: Effects of carbon nanotubes on human monocytes. Natural compounds and their role in apoptotic cell signalling pathways. Ann N Y Acad Sci 2009, 1171:600-605.

46. Hirano S, Kanno S, Furuyama A: Multi-walled carbon nanotubes injure the plasma membrane of macrophages. Toxicol Appl Pharmacol 2008, 232:244-251.

47. Simon A, Reynaud C, Mayne M, Herlin N, Desqueyroux H, Gouget B, Carriere M: Cytotoxicity of metal oxide nanoparticles and multiwalled carbon nanotubes to lung, kidney and liver cells. Met lons Biol Med 2008, 10:310-314.

48. Reddy ARN, Reddy YN, Krishna DR, Himabindu V: Multi walled carbon nanotubes induce oxidative stress and cytotoxicity in human embryonic kidney (HEK293) cells. Toxicology 2010, 272:11-16.

49. Ursini CL, Cavallo D, Fresegna AM, Ciervo A, Maiello R, Buresti G, Casciardi S, Tombolini F, Bellucci S, lavicolli S: Comparative cyto-genotoxicity assessment of functionalized and pristine multi-walled carbon nanotubes on human lung epithelial cells. Toxicol In Vitro 2012, 26:831-840.

50. Cavallo D, Fanizza C, Ursini CL, Casciardi S, Paba E, Ciervo A, Fresegna AM, Buresti G, Tombolini F, Bellucci S, lavicolli S: Multi-walled carbon nanotubes induce cytotoxicity and genotoxicity in human lung epithelial cells. J Appl Toxicol 2012, 32:454-464.

51. Zuo N, Suzuki Y, Sugaya T, Osaki K, Kanaguchi Y, Wang LN, Tomino Y: Protective effects of tubular liver type fatty acid-binding protein against glomerular damage in murine IgA nephropathy. Nephrol Dial Transplant 2011, 26:2127-2137.

52. Wittlinger M, Schlapfer M, De Conno E, Zgraggen BR, Reyes L, Booy C, Schimmer RC, Seifert B, Burmeister MA, Spahn DR, Beck-Schimmer B: The effect of hydroxyethyl starches (HES 130/0.42 and HES 200/0.5) on activated renal tubular epithelial cells. Anesth Analg 2010, 110:531-540.

53. Zehnder D, Quinkler M, Eardley KS, Bland R, Lepenies J, Hughes SV, Raymond NT, Howie AJ, Cockwell P, Stewart PM, Hewiston M: Reduction of the vitamin $D$ hormonal system in kidney disease is associated with increased renal inflammation. Kidney Int 2008, 74:1343-1353.

doi:10.1186/1471-2369-14-96

Cite this article as: Kermanizadeh et al.: An in vitro assessment of panel of engineered nanomaterials using a human renal cell line: cytotoxicity, pro-inflammatory response, oxidative stress and genotoxicity. BMC Nephrology 2013 14:96

\section{Submit your next manuscript to BioMed Central and take full advantage of:}

- Convenient online submission

- Thorough peer review

- No space constraints or color figure charges

- Immediate publication on acceptance

- Inclusion in PubMed, CAS, Scopus and Google Scholar

- Research which is freely available for redistribution 